\begin{abstract}
"Mircea cel Batran" Naval Academy Scientific Bulletin, Volume XIX - 2016 - Issue 2
The journal is indexed in: PROQUEST / DOAJ / Crossref / EBSCOhost / INDEX COPERNICUS / DRJI / OAJI /

JOURNAL INDEX I I2OR / SCIENCE LIBRARY INDEX / Google Scholar / Academic Keys/ ROAD Open Access I Academic Resources / Scientific Indexing Services / SCIPIO / JIFACTOR
\end{abstract}

\title{
LEARNING, TEACHING AND OUR BRAIN
}

\author{
Dana ZECHIA ${ }^{1}$ \\ Alina BALAGIU² \\ ${ }^{1}$ Senior Lecturer, Ph.D. „Mircea cel Bătrân” Naval Academy, Constanta \\ ${ }^{2}$ Assistant Professor, Ph.D. „Mircea cel Bătrân” Naval Academy, Constanta
}

\begin{abstract}
Learning and teaching have always been two parts of the educational process. What is the role of our brain in this activity? How do we learn or how do we teach so that the final effects to have the desired results? Learning as a process has always had competitors such as forgetfulness, interruption, laziness, ignorance or even quitting. Teaching is a complex, multifaceted activity, often requiring us as instructors to juggle multiple tasks and goals simultaneously and flexibly. On the other hand the brain is thoroughly involved in, and connected with, everything educators and students do not only at school but also outside it.
\end{abstract}

There has always been a question on how we learn, on the capacity of our brain to imbibe in this delicate process. How much is science and how much is based on our own instincts? The lifestyle we have nowadays does not necessarily mean sitting at a desk with all your books or notebooks around you. This traditional type of knowledge intake leads to some downsides on a psychological level. We sometimes have the strange feeling that we have not done the right thing and this might cause a high level of stress. A lot of students have come to the idea that learning leads to a high level of strain.

Learning as a process has always had competitors such as forgetfulness, interruption, laziness, ignorance or even quitting. Nowadays a lot of scientists have sustained the idea that these enemies are also important because they clean our memory and filter the information. They also make our brain work better and store ideas more powerfully.

We nourish the idea that changing the learning environment has rich effects while turning the student into a more independent person. Team learning when you are really interested in a subject helps you change ideas, discuss the topic and reach a deeper level of understanding. Learning is a cognitive operation taking place all our life whether in school or workplace.

As a student I remember cramming for exams. It was like a crisis stage forcing our brain to gorge on lesson after lesson, course after course. Now I realize that it did not mean long term learning. Most of the information having been acquired was forgotten after the test. If we want to have the knowledge in our mind on a long term basis the need to revise followed by forgetting and then study again is imperative. Another basic idea is understanding the process or the subject we are leaning about which leads to a lot less forgetfulness on the matter.

Then, revising the amount of information but without flipping through your notes helps you recall. At the same time you become aware of what you have already forgotten. Thus you can review. But what are we doing with distraction? We, and especially the young generation lives in an era of smart phones, all sorts of electronic gadgets, social media feeds. They do act like distracters, but is it really that bad? Do they only have negative effects on the way we learn? Well, sometimes it is not that bad to switch to something completely different and clean your mind to be able to go back completely fresh and with your attention wide awake.

When I asked my students about their methods of learning I received several and completely different answers. Some of the mentioned learning while listening to music, some others said they could only learn at night when there was no sound distraction; part of them told me that concentration is the most important, being able to switch off completely when in need of study. They also mentioned that distracters hindered them when it was the case to show continuous focus like for example listening to a lecture.

I have also tried to find out what they think about learning as a lifelong process. Some mentioned that learning ends up when people finish attending any type of educational system. Others expressed the idea that we never stop learning, acquiring more and more info if we wish to be deeply rooted into the present and never lose touch with change. The latter said that everything is linked with being flexible and adaptable to the world around us.

Their conclusion was that learning is not only about getting better grades but also about carrying on in life, finding out what their personal abilities are and about taking the best of decisions. Knowing how our brain basically learns can offer us help in terms our expectations on reliable academic routines. Learning happens all the time in many different ways and only when they are able to study their own habits they will be 
"Mircea cel Batran" Naval Academy Scientific Bulletin, Volume XIX - 2016 - Issue 2 Academic Resources / Scientific Indexing Services / SCIPIO I JIFACTOR

able make any necessary changes. This may be a good method to evaluate their innate abilities.

When I think about my profession I know how truly personal it is. Very few people realize what it means to teach or the outcome valuable teaching can have on someone's life. Teachers offer a great deal of themselves to their students along the way leading to raising trust and care. They are not only information providers but also trainers, mentors, educators, pedagogues or role-models.

Teachers work along with their students through each pivotal stage of their development. A big part of what they learn from their greatest teachers is never related to a syllabus. They help students grow and become responsible at the same time. As a teacher I have always showed my students how to become independent and carefully guided them when necessary. School has constantly been not only a place of academic learning but also one of social learning.

It is not an exaggeration to say that a great teacher can change a student's life. To be a great educator you must connect with your students and reach them on multiple levels, because the best teachers are committed to their students' wellbeing inside and outside their classroom. Inspiring students is vital for ensuring their success and encouraging them to fulfill their potential.
Teaching and learning are two important parts of the process of education.

Teachers can also be a devoted source of advice for students when thinking and taking the most important decisions in their lives. Educators' role is not only teaching but also helping them pursue career opportunities by preparing themselves thoroughly. Teaching is a complex, multifaceted activity, often requiring us as instructors to juggle multiple tasks and goals simultaneously and flexibly. The conclusion is that our brain has always been connected to what we do all the time. Brain-based education can best be understood in three words: engagement, strategies and principles.

As a conclusion we may ask ourselves one question. Is there any value in discussing learning and teaching theories? Though some of these theories appeared many years ago and have their roots in individual experiences, they can also be adapted and used nowadays to highlight the changes in education and the world of today. Students learn in numerous ways unique to their development, environment and involvement. Everybody has the innate ability to learn; it is the method, speed and desire that teachers apply to help their students learn successfully.

\section{BIBLIOGRAPHY}

[1] Schunk, D. H. (2008). Learning theories: an educational perspective. Upper Saddle River, NJ: Pearson Prentice Hall. 